\title{
The maximum oxygen consumption and body structure component of women at the first period of mature age with a different somatotypes
}

\author{
Miroshnichenko V.M. ${ }^{1 \mathrm{ABCD}}$, Salnykova S.V. ${ }^{2 \mathrm{ABCDE}}$, Brezdeniuk O.Y. ${ }^{1 \mathrm{ABCD}}$, Nesterova S.Y. ${ }^{3 \mathrm{ABCD}}$, Sulyma A.S. ${ }^{3 \mathrm{ABCD}}$, \\ Onyshchuk V.E. ${ }^{3 \mathrm{ABCD}}$, Gavrylova N.V. ${ }^{3 \mathrm{ABCD}}$ \\ ${ }^{1}$ Department of Physical Education, Vinnytsia Mykhailo Kotsiubynskyi State Pedagogical University, Ukraine; \\ ${ }^{2}$ Department of Philosophy and Economic, Vinnytsia Institute of Trade and Economics of Kyiv National University of \\ Trade and Economics, Ukraine; \\ ${ }^{3}$ Department of Medical and Biological Foundations of Physical Education and Physical Rehabilitation, Faculty of \\ Physical Education, Vinnytsia Mykhailo Kotsiubynskyi State Pedagogical University, Ukraine
}

Authors' Contribution: A - Study design; B - Data collection; C - Statistical analysis; D - Manuscript Preparation; E - Funds Collection.

\begin{tabular}{|c|c|}
\hline 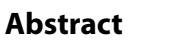 & \\
\hline Purpose: & $\begin{array}{l}\text { the identification of features of the maximum oxygen consumption of women in the first period of mature } \\
\text { age and connection with body structure component. }\end{array}$ \\
\hline Material: & $22-35$ years old women $(n=210)$ have participated in a research. \\
\hline Results: & $\begin{array}{l}\text { It was determined that women with endomorphic and mesomorphic somatotype prevail according to the } \\
\text { absolute measure } \mathrm{VO}_{2 \max } \text {. They have large body weight and higher percentage content of the muscular } \\
\text { component. The women with low body weight and low values of fat component prevail according to a } \\
\text { relative measure } \mathrm{VO}_{2 \text { max }} \text {. Large body weight in women of endomorphic, endomorphic and mesomorphic } \\
\text { somatotype stipulates low values of a relative measure } \mathrm{VO}_{2 \max } \text {. It is indicated by the high degree of the return } \\
\text { correlation between a relative measure } \mathrm{VO}_{2 \max } \text { and body weight. }\end{array}$ \\
\hline Conclusions: & $\begin{array}{l}\text { The relative measure } \mathrm{VO}_{2 \text { max }} \text { is considered more informative as its dependence on body weight is leveled. } \\
\text { The obtained data indicate the advantage according to a relative measure } \mathrm{VO}_{2 \text { max }} \text { of women with low body } \\
\text { weight somatotype (ectomorphic and balanced). Such feature is explained by authentically low percentage } \\
\text { content of the fat component in women. }\end{array}$ \\
\hline
\end{tabular}

\section{Introduction}

The doctrine concerning the constitutional types is that each somatotype has peculiar characteristics of structure and function of internal organs. Therefore somatotype defines physical development and functionality of an organism [1]. The method of exercises execution in sport corrects and performs distribution of physical activities considering somatotype [2]. This feature is widely applied for the purpose of selection and sports orientation. The efficiency of somatotype application for sports selection of mountain climbers is confirmed by the research of Davide [3]. Helena [4] proves the need to consider somatotype and body component structure for sports orientation in sports dances, modern dances, and the ballet. The consideration of morphological features didn't come into common use in practice of improving physical culture. Respectively there is a limited quantity of scientific works devoted to this subject.

The measure of the maximum oxygen consumption $\left(\mathrm{VO}_{2 \max }\right)$ characterizes the power of aerobic processes of person power supply. In the general energy potential of the person, aerobic energy supply considerably prevails anaerobic.Aerobic potentials of the person are an integrated indicator of a functional condition of many systems of

\footnotetext{
(C) Miroshnichenko V.M., Salnykova S.V., Brezdeniuk O.Y., Nesterova S.Y., Sulyma A.S., Onyshchuk V.E., Gavrylova N.V., 2018
}

doi:10.15561/18189172.2018.0505 an organism [1]. Our previous research has found out features of display the maximum oxygen consumption in 17-19 years old students with different somatotypes [5] and in men of the first period of mature age [6]. Also, we investigated the level of aerobic potentials in women of the first period of mature age, but differences of somatotypes weren't investigated [7]. Yoo-rim et al [8] determined the features of the maximum oxygen consumption in students with different somatotypes. Studies of Goran et al [9] defined the reliable differences of $\mathrm{VO}_{2 \text { max }}$ measure in the military seamen with different somatotypes. Chaouachi et al [10] prove a major role of dominating somatotype at the aerobic training. There are no scientific publications devoted to the special display of an absolute and relative measure of $\mathrm{VO}_{2 \max }$ in women with different somatotypes of the first period of mature age.

There are publications which proved the major influence of body weight component structure on the functionality of the person. Brezdeniuk [11] investigated features of display of aerobic and anaerobic opportunities of 17-21 years old students' organism. The author determined that students with "low" and "normal" content of fat component have the "excellent" level of aerobic opportunities. Also, students with "high" and "very high" content of muscular component have the "excellent" level of aerobic opportunities. Sukanta [12] revealed that the body component structure correlates well with $\mathrm{VO}_{2 \text { max }}$. Venkata et al [13] define the powerful influence of body 
component structure on the possibilities of runners to increase the $\mathrm{VO}_{2 \max }$ level. Goran et al [9] determined that higher values of percentage content of fat component have a negative effect on aerobic and anaerobic opportunities of the military seamen. The negative impact of endomorphy on aerobic opportunities is also determined in research of Alkandari and Barac [14]. Neha et al [15] have proved the connection between of growth, body weight and age with $\mathrm{VO}_{2 \max }$ in women of the second period of mature age.

There are data that point out the variability of the component body structure in the course of a person's ontogenesis. G. Kaur et al. specify that with the increase of years the endomorphic and mesomorphic component in women decreases [16]. Salnykova S. proves that during ontogenesis from 30 to 40 years the content of the fat component in women increases, and muscular component decreases [7]. In view of contradictory information, it is important to investigate the component body structure of all age groups women.

Lizana et al [17] proved the influence of the social and economic status on the component body structure of 6-18 years old Chilean girls. We haven't found research of component structure of body weight and its influence on aerobic opportunities of women of the first period of mature age.

The research of the maximum oxygen consumption and component body structure in women of the first to the period of mature age will allow to define features of their display depending on a somatotype. Correlation connection between component body structure with $\mathrm{VO}_{2}$ will find the influence of each of the components on aerobic opportunities of women of the first period of mature age. There will be defined features of the influence of each body components on women with different somatotypes. It can be developed the improving training programs considering the morphological characteristics which will improve their efficiency on the basis of the obtained data.

The purpose of the research objective consists in the identification of features of the maximum oxygen consumption in women with different somatotypes of the first period of mature age and a research of connection with body component structure.

\section{Material and methods.}

Participants. 22-35 years old women $(n=210)$ have participated in a research. All women were from the main medical group and didn't go in for sports the last 5 years. All investigated persons have agreed to participate in an experiment.

Design of the research. The maximum measure of oxygen consumption $\left(\mathrm{VO}_{2 \text { max }}\right)$ was determined by the Karpman and Gudkov method [18]. Investigated person performed two loads on bicycle ergometer by $5 \mathrm{~min}$. The frequency of pedaling was $60 \mathrm{rpm}^{-1}$ with 3 min interval of rest. Power of the first load was $1 \mathrm{~W}$ on $1 \mathrm{~kg}$ of body weight. Power of the second load was $2 \mathrm{~W}$ on $1 \mathrm{~kg}$ of body weight. The heart rate was registered at the end of each load. The value of $\mathrm{VO}_{2 \max }$ was calculated. The value of $\mathrm{VO}_{2 \max }$ is calculated in $\mathrm{ml} \cdot \mathrm{min}^{-1}$

The component body structure was determined by the method of a bioelectric impedance with the help of OMRON BF-511. This device analyzes the passing of current through an organism. The device considers a low ability to carry electric current by fat tissue and high conductivity of the muscular tissue. The device's indicators determined the percentage of fat tissue in an organism; the percentage of skeletal muscles in an organism and body weight.

Somatotype was defined according to the Carter method [19]. This method is based on the complex assessment of relative obesity - endomorphy; relative development of skeletal and muscular system mesomorphy; relative linearity (elongation) of a body - ectomorphy. The following anthropometrical research was performed for this purpose: growth, body weight, circumference sizes, cross diameters and thickness of skin and fat rolls were determined. The thickness of skin and fat rolls were measured by means of KETs-100 caliper: on the back surface of a shoulder; under a bladebone; on the side surface of a body. The circumferences sizes of an intense shoulder and shin were measured in places of the greatest development by a measuring tape. Cross diameter of the distal part of a shoulder and a distal part of a hip was measured by a caliper. The numerical expression of each component was received by mathematical calculation [19]. Belonging to a somatotype was defined according to the advantage of a component in 2,5 points. In the absence of such an advantage, the investigated person was determined as the balanced somatotype. All women were conditionally distributed on groups according to different somatotypes.

It was compared the average group value of measures in women with different somatotypes.

Statistical analysis. The analysis of the obtained data was carried out with the application of Excel 2010. The independent samples were compared for the analysis of the studied measures. Ranks of distribution displayed indicators features according to women's somatotypes. Statistical processing was performed applying Student's $\mathrm{t}$-criterion. It was defined as an average mean $(\overline{\mathrm{X}})$, Student's t-criterion $(\mathrm{t})$, standard error of the mean $( \pm \mathrm{m})$, number of degrees of freedom (f), significance value (p). The difference was considered significant at $p<0,05$.

The correlation analysis was performed to determine the interrelation between the studied measures. The correlation coefficient (r) was defined. The number of degrees of freedom (k) was calculated. The $a$ is the tabular coefficient of correlation which corresponds to the certain level of significance was calculated by means of tabular data. The significance of correlation coefficient was checked in comparison the obtained data with tabular. The connection considered significant at $\mathrm{p}<$ 0,05 . The gradation proposed by Cheddok was applied for the determination of constraint force. According to this technique the constraint force was estimated as follows: $0,1 \leq \mathrm{r}<0,3$-weak; $00,3 \leq \mathrm{r}<0,5$ - moderate; $0,5 \leq \mathrm{r}<$ 0,7 - average; $0,7 \leq \mathrm{r}<0,9-$ high; $0,9 \leq \mathrm{r} \leq 0,99$ - very 
high [20].

\section{Results}

The research of the maximum oxygen consumption in women with different somatotype has allowed to find out the following features. The reliably higher values of an absolute measure of $\mathrm{VO}_{2 \text { max }}$ have women with large body weight somatotypes (endomorphic and endomorphic and mesomorphic). Such tendency indicates the dependence of an absolute measure of $\mathrm{VO}_{2 \text { max }}$ on the body weight (table 1,2).

The women with different somatotypes have other tendencies according to relative measure of $\mathrm{VO}_{2}$ max The women with low body weight somatotype have authentically higher values of a relative measure of $\mathrm{VO}_{2}$
The women with endomorphic, endomorphic and mesomorphic somatotype have the highest percentage content of fat according to the results of bioelectric impedance. The highest percentage content of muscular component has women with ectomorphic somatotype. The reliably lowest percentage content muscular component has women with endomorphic somatotype (table 2).

The performed correlation analysis between the maximum oxygen consumption and body component structure of women with different somatotypes has found the following tendencies. The women with endomorphic somatotype have direct moderate connection only between a relative measure of $\mathrm{VO}_{2 \text { max }}$ and a muscular body component. The women of others somatotypes have no significant correlation connection (table $3,4,5,6)$. $\max$.

Table 1. Power measures of aerobic productivity and women body weight

\begin{tabular}{|c|c|c|c|c|c|c|c|c|}
\hline \multirow[t]{2}{*}{ Measures } & \multicolumn{4}{|c|}{$\begin{array}{l}\text { Average mean, } \bar{X} \pm m \\
\text { endomorphy } \\
\begin{array}{ll}\text { somatotype } & \text { ectomorphy } \\
n=49 & \text { somatotype } n=49\end{array}\end{array}$} & \multicolumn{2}{|c|}{$\begin{array}{l}\text { endomorphic and } \\
\text { mesomorphic } \\
\text { somatotype } n=58\end{array}$} & \multicolumn{2}{|c|}{$\begin{array}{l}\text { balanced } \\
\text { somatotype } n=54\end{array}$} \\
\hline & $\overline{\mathrm{X}}$ & $\mathbf{m}$ & $\overline{\mathrm{X}}$ & $\mathbf{m}$ & $\overline{\mathrm{X}}$ & m & $\bar{X}$ & $\mathbf{m}$ \\
\hline $\mathrm{VO}_{2 \max }\left(\mathrm{ml} \cdot \mathrm{min}^{-1}\right)$ & $\begin{array}{c}2509,9 \\
\bullet \bullet \bullet \\
\square\end{array}$ & 16,59 & $\begin{array}{c}2487,0 \\
\bullet \bullet \bullet\end{array}$ & 34,69 & 2681,1 & 25,30 & $\begin{array}{c}2445,2 \\
\bullet \bullet \bullet\end{array}$ & 27,19 \\
\hline $\mathrm{VO}_{2 \max }\left(\mathrm{ml} \cdot \mathrm{min}^{-1} \cdot \mathrm{kg}^{-1}\right)$ & 37,8 & 0,46 & $\begin{array}{l}45,2 \\
\bullet \bullet \bullet \\
\circ \circ \bigcirc\end{array}$ & 0,56 & $\begin{array}{l}40,5 \\
\circ \circ \bigcirc\end{array}$ & 0,47 & $\begin{array}{l}44,1 \\
\bullet \bullet \bullet \\
\circ \circ ०\end{array}$ & 0,63 \\
\hline
\end{tabular}

Notes: The reliability of measures' difference: $\bigcirc$ - relating to endomorphic somatotype; $\mathbf{-}$ - relating to balanced somatotype; $\bullet-$ relating to endomorphic and mesomorphic somatotype. The quantity of marks corresponds to: $\mathbf{\square}-p$ $<0,05 ; \bullet \bullet \bullet$, , o $-(p<0,001)$

Table 2. The body component structure and women body weight

\begin{tabular}{|c|c|c|c|c|c|c|c|c|}
\hline \multirow[t]{2}{*}{ Measures } & \multicolumn{2}{|c|}{$\begin{array}{l}\text { endomorphy } \\
\text { somatotype } \\
n=49\end{array}$} & \multicolumn{2}{|c|}{$\begin{array}{l}\text { endomorphy } \\
\text { somatotype } \\
n=49\end{array}$} & \multicolumn{2}{|c|}{$\begin{array}{l}\text { endomorphy } \\
\text { somatotype } \\
n=49\end{array}$} & \multicolumn{2}{|c|}{$\begin{array}{l}\text { endomorphy } \\
\text { somatotype } \\
\mathrm{n}=49\end{array}$} \\
\hline & $\overline{\mathrm{X}}$ & $\mathrm{m}$ & $\bar{X}$ & $\mathrm{~m}$ & $\overline{\mathrm{X}}$ & $\mathrm{m}$ & $\overline{\mathrm{X}}$ & $\mathrm{m}$ \\
\hline \multicolumn{9}{|c|}{ Indicators of a bioelectric impedance } \\
\hline $\begin{array}{l}\text { Content of fat in an } \\
\text { organism (\%) }\end{array}$ & $\begin{array}{l}34,4 \\
* * * \\
\bullet \bullet \bullet\end{array}$ & 0,13 & 23,4 & 0,21 & $\begin{array}{l}32,1 \\
* * * \\
\square\end{array}$ & 0,20 & $\begin{array}{l}28,7 \\
* * * \\
000\end{array}$ & 0,26 \\
\hline $\begin{array}{l}\text { The content of muscles in } \\
\text { an organism (\%) }\end{array}$ & 28,7 & 0,19 & $\begin{array}{l}31,1 \\
\circ \circ \circ\end{array}$ & 0,17 & $\begin{array}{l}30,3 \\
\circ \circ \bigcirc \\
* *\end{array}$ & 0,18 & $\begin{array}{l}29,9 \\
000 \\
* * *\end{array}$ & 0,15 \\
\hline Body weight (kg) & $\begin{array}{l}66,7 \\
* * * \\
\mathbf{m}\end{array}$ & 0,64 & 55,1 & 0,57 & $\begin{array}{l}66,7 \\
* * * \\
\mathbf{a} \\
\end{array}$ & 1,06 & 55,8 & 0,63 \\
\hline
\end{tabular}

Notes: The reliability of indicators' difference: $\bigcirc$ - relating to endomorphic somatotype; * - relating to ectomorphic somatotype; $\mathbf{-}$ - relating to balanced somatotype; $\bullet$ - relating to endomorphic and mesomorphic somatotype. The quantity of marks corresponds to: ${ }^{* *}-(p<0,01), * * *, \bullet \bullet \bullet, \mathbf{a n}, \circ \circ \circ-(p<0,001)$. 
Table 3. Interrelation of the maximum oxygen consumption of with body weight and body component structure of women (endomorphic somatotype)

\begin{tabular}{|c|c|c|c|c|c|c|c|c|c|}
\hline \multirow{2}{*}{ Measures } & \multicolumn{3}{|c|}{ Fat component } & \multicolumn{3}{|c|}{ Muscular component } & \multicolumn{3}{|c|}{ Body weight } \\
\hline & $r$ & $a$ & $\mathbf{p}$ & $r$ & $a$ & $\mathbf{p}$ & $\mathbf{r}$ & $a$ & $\mathbf{p}$ \\
\hline $\begin{array}{l}\mathrm{VO}_{2 \max } \\
\left(\mathrm{ml} \cdot \mathrm{min}^{-1}\right)\end{array}$ & 0,056 & 0,304 & $p>0,05$ & 0,009 & 0,304 & $p>0,05$ & 0,345 & 0,304 & $p<0,05$ \\
\hline $\begin{array}{l}\mathrm{VO}_{2 \max }\left(\mathrm{ml} \cdot \mathrm{min}^{-}\right. \\
\left.{ }^{1} \cdot \mathrm{kg}^{-1}\right)\end{array}$ & $-0,193$ & 0,304 & $p>0,05$ & 0,381 & 0,304 & $p<0,05$ & $-0,814$ & 0,490 & $p<0,001$ \\
\hline
\end{tabular}

Notes: $r$ - correlation coefficient; $a$ - tabular correlation coefficient; $p$ - significance level.

Table 4. Interrelation of the maximum oxygen consumption with body weight and body component structure of women (ectomorphic somatotype)

\begin{tabular}{|c|c|c|c|c|c|c|c|c|c|}
\hline \multirow{2}{*}{ Measures } & \multicolumn{3}{|c|}{ Fat component } & \multicolumn{3}{|c|}{ Muscular component } & \multicolumn{3}{|c|}{ Body weight } \\
\hline & $r$ & $a$ & $\mathbf{p}$ & $r$ & $a$ & $\mathbf{p}$ & $r$ & $a$ & $\mathbf{p}$ \\
\hline $\begin{array}{l}\mathrm{VO}_{2 \max } \\
\left(\mathrm{ml} \cdot \mathrm{min}^{-1}\right)\end{array}$ & 0,053 & 0,304 & $p<0,05$ & 0,055 & 0,304 & $p<0,05$ & 0,381 & 0,304 & $p<0,05$ \\
\hline $\begin{array}{l}\mathrm{VO}_{2 \max }\left(\mathrm{ml} \cdot \mathrm{min}^{-}\right. \\
\left.{ }^{1} \cdot \mathrm{kg}^{-1}\right)\end{array}$ & 0,106 & 0,304 & $p<0,05$ & $-0,109$ & 0,304 & $p<0,05$ & $-0,471$ & 0,393 & $p<0,01$ \\
\hline
\end{tabular}

Notes: $r$-correlation coefficient; $a$ - tabular correlation coefficient; $\mathrm{p}$ - significance level.

Table 5. Interrelation of the maximum consumption of oxygen with body weight and body component structure of women (endomorphic and mesomorphic somatotype)

\begin{tabular}{|c|c|c|c|c|c|c|c|c|c|}
\hline \multirow{2}{*}{ Measures } & \multicolumn{3}{|c|}{ Fat component } & \multicolumn{3}{|c|}{ Muscular component } & \multicolumn{3}{|c|}{ Body weight } \\
\hline & $r$ & $a$ & $\mathbf{p}$ & $r$ & $a$ & $\mathbf{p}$ & $\mathbf{r}$ & $a$ & $\mathbf{p}$ \\
\hline $\begin{array}{l}\mathrm{VO}_{2 \max } \\
\left(\mathrm{ml} \cdot \mathrm{min}^{-1}\right)\end{array}$ & $-0,144$ & 0,304 & $p>0,05$ & 0,154 & 0,304 & $p>0,05$ & 0,351 & 0,304 & $p<0,05$ \\
\hline $\begin{array}{l}\mathrm{VO}_{2 \max }\left(\mathrm{ml} \cdot \mathrm{min}^{-}\right. \\
\left.{ }^{1} \cdot \mathrm{kg}^{-1}\right)\end{array}$ & $-0,261$ & 0,304 & $p>0,05$ & 0,290 & 0,304 & $p>0,05$ & $-0,792$ & 0,490 & $p<0,001$ \\
\hline
\end{tabular}

Notes: $r$ - correlation coefficient; $a$ - tabular correlation coefficient; $p$ - significance level.

Table 6. Interrelation of the maximum oxygen consumption with body weight and component body structure of women (balanced somatotype)

\begin{tabular}{|c|c|c|c|c|c|c|c|c|c|}
\hline \multirow{2}{*}{ Measures } & \multicolumn{3}{|c|}{ Fat component } & \multicolumn{3}{|c|}{ Muscular component } & \multicolumn{3}{|c|}{ Body weight } \\
\hline & $r$ & $a$ & $\mathbf{p}$ & $r$ & $a$ & $\mathbf{p}$ & $\mathbf{r}$ & $a$ & $\mathbf{p}$ \\
\hline 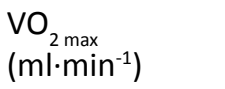 & $-0,004$ & 0,304 & $p>0,05$ & 0,120 & 0,304 & $p>0,05$ & 0,351 & 0,304 & $p<0,05$ \\
\hline $\begin{array}{l}\mathrm{VO}_{2 \max }\left(\mathrm{ml} \cdot \mathrm{min}^{-}\right. \\
\left.{ }^{1} \cdot \mathrm{kg}^{-1}\right)\end{array}$ & $-0,239$ & 0,304 & $p>0,05$ & $-0,103$ & 0,304 & $p>0,05$ & $-0,663$ & 0,490 & $\mathrm{p}<0,001$ \\
\hline
\end{tabular}

Notes: $r$ - correlation coefficient; $a$ - tabular correlation coefficient; $p$ - significance level.

The correlation relations between an absolute measure of $\mathrm{VO}_{2 \max }$ and women body weight of all studied somatotypes are characterized as direct connection of the moderate force (tab. 3, 4, 5, 6). The women with different somatotypes have stronger correlation relations between a relative measure of $\mathrm{VO}_{2 \max }$ and body weight. The women with endomorphic somatotypes have the reverse high level connection (tab. 3). The women with ectomorphic somatotypes have the reverse connection of the moderate force between a relative measure of $\mathrm{VO}_{2 \text { max }}$ and body weight (tab. 4). The women with endomorphic and mesomorphic somatotype have the reverse connection of the high force between a relative measure of $\mathrm{VO}_{2 \text { max }}$ and body weight (tab. 5).

The women with balanced somatotype have reverse connection of average force between a relative measure of $\mathrm{VO}_{2 \max }$ and body weight (tab. 6). 


\section{Discussion.}

It is known that the absolute measure of $\mathrm{VO}_{2}$ max to a certain extent depends on body weight. The data of table 2 indicate the absence of a difference between the body weight of women with endomorphic and mesomorphic somatotype and women with endomorphic somatotype. At the same time we define significantly higher values of an absolute measure of $\mathrm{VO}_{2 \text { max }}$ in women with endomorphic and mesomorphic somatotype in relation to women with endomorphic somatotype. Such phenomenon can be explained to large percentage content of fat component in women with endomorphic somatotype. Besides the highest values of an absolute measure of $\mathrm{VO}_{2}$ max in women with endomorphic and mesomorphic somatotype are caused by large percentage content of muscular component. Data concerning negative impact of fat component to the level of $\mathrm{VO}_{2}$ is confirmed by the research of Goran et al [9], Alkandari and Barac [14]. We have found significantly the highest values of absolute measure of $\mathrm{VO}_{2 \text { max }}$ in women with endomorphic and mesomorphic somatotype in relation to women with ectomorphic and balanced somatotype. It can be explained by the significantly large body weight at women with endomorphic and mesomorphic somatotype. Existence of the highest values of percentage content of fat component in women with endomorphic and mesomorphic somatotype is compensated to considerable percentage content of muscular component (tab. 2). We have found authentically the highest absolute measure of $\mathrm{VO}_{2 \max }$ in women with endomorphic somatotype in relation to women with balanced somatotype. It can be explain by with the large body weight of women with endomorphic somatotype. The determined features of display of an absolute measure of $\mathrm{VO}_{2 \text { max }}$ in 22-35 years old women with different somatotypes coincide with our previous research [5].

The relative measure of $\mathrm{VO}_{2 \text { max }}$ is considered more informative as its dependence on body weight is leveled. The obtained data indicate advantage according to relative measure of $\mathrm{VO}_{2 \text { max }}$ in women with low body weight somatotypes (ectomorphic and balanced). Such feature we explain by significantly low percentage content of fat component in women of ectomorphic and balanced somatotype (tab. 2). It is revealed the advantage of women with endomorphic and mesomorphic somatotype over women with endomorphic somatotype according to the relative measure of $\mathrm{VO}_{2 \text { max }}$. It provides large percentage content of muscular component in women with endomorphic and mesomorphic somatotype. The obtained data coincide with our previous research performed with 17-19 years old girls [5].

We performed the correlation analysis of absolute and relative measures of $\mathrm{VO}_{2 \text { max }}$ with component body structure of women with different somatotypes. The analysis revealed only direct moderate connection of relative measure of $\mathrm{VO}_{2 \text { max }}$ with a muscular component in women with endomorphic somatotype (tab. 3). It isn't revealed other research devoted to such correlation communications in 22-35 years women which have different somatotypes. Sukanta Saha determined correlation connection of $\mathrm{VO}_{2 \max }$ with all components of a body in students of colleges [12]. The negative correlation of $\mathrm{VO}_{2 \text { max }}$ with a fat component was found also by Goran et al [9] in the military seamen. Authors indicate the need to consider the content of fat and muscular component in evaluation of body weight and $\mathrm{VO}_{2 \max }$. We take into consideration the tendencies found out by other authors. But it is incorrectly to compare our and their obtained data: the contingent of investigated persons and methods of component body structure determination is rather differs.

The analysis of dependence the body weight on absolute and relative measures of $\mathrm{VO}_{2}$ max has found out the presence of the correlation relations in women of all somatotypes. The connection of an absolute measure of $\mathrm{VO}_{2 \max }$ with body weight in women of all studied somatotype is characterized as direct moderate. The correlation analysis of a relative measure of $\mathrm{VO}_{2}$ $\max _{\text {ax }}$ with body weight has found out reverse connection in women of all studied somatotypes. The high force of reverse connection of a relative measure of $\mathrm{VO}_{2 \max }$ with body weight is defined in women with endomorphic, endomorphic and mesomorphic somatotypes (tab. 3, 5). It should be noted that women of these somatotypes have significantly large body weight. The women with balanced somatotype have average reverse connection (tab. 6). The women with ectomorphic somatotype have reverse moderate connection (tab. 4). In the previous research we didn't performed the correlation analysis between an measure of $\mathrm{VO}_{2 \text { max }}$ and body weight of women with different somatotypes. But in the previous research we have found direct connection of moderate force between an absolute measure of $\mathrm{VO}_{2 \text { max }}$ and body weight in 17-19 years old girls (without considering somatotype) [5]. Also was found out the reverse connection of average force between a relative measure of $\mathrm{VO}_{2 \text { max }}$ and body weight in 17-19 years girls (without considering somatotype) [5]. We haven't found out in literature the available data concerning the correlation relations of $\mathrm{VO}_{2 \max }$ with the body weight of women with different somatotypes of the first period of mature age.

\section{Conclusions.}

It is determined the features of display the maximum oxygen consumption in 22-35 years old women with different somatotypes. The women with large body weight somatotype and higher percentage content of muscular component prevail according to the absolute measure of $\mathrm{VO}_{2 \max }$. The women with low body weight somatotype and low values of fat component prevail according to the relative measure of $\mathrm{VO}_{2 \text { max }}$

Large body weight in women with endomorphic, endomorphic and mesomorphic somatotypes causes low values of a relative measure $\mathrm{VO}_{2 \text { max }}$. It is indicated by high degree of the reverse correlation between a relative measure of $\mathrm{VO}_{2 \text { max }}$ and body weight in women of these somatotypes. 


\section{Acknowledgements}

We express gratitude to professor of Furman Yuriy Mykolayovych for intellectual, organizational and methodical support of the conducted research. This work is performed according to the plan of research work of Vinnytsia Pedagogical University according to the subject
9027 "Optimization of improvement process of physical and functional fitness of student's and student's youth physical activities of the different direction" (registration number 0113U007491).

\section{Conflict of interests.}

Authors declare that there is no conflict of interests.

\section{References}

1. Furman YM, Miroshnichenko VM, Drachuk SP. Promising models of health related physical culture technologies in physical education of higher educational establishments' students. Kiev, Olympic Literature; 2013. (in Ukrainian)

2. Platonov VN. System of sportsmen's training in Olympic sports. Kiev: Olympic Literature; 2004. (in Russian).

3. Davide Barbieri, Luciana Zaccagni, Annalisa Cogo, and Emanuela Gualdi-Russo. High Altitude Medicine \& Biology. 2012; 13(1): 46-50. https://doi.org/10.1089/ham.2011.1062

4. Helena Liiv. Anthropometry, body composition and aerobic capacity in elite DanceSport athletes compared with ballet and contemporary dancers. University of Tartu Press; 2014.

5. Miroshnichenko VM. The use of physical training of different directions for the perfection of physical health of girls depends on somatic types. Cand. Diss. Lviv; 2008. (in Ukrainian)

6. Miroshnichenko VM. Characteristic of aerobic potentials in men of first mature age with a different somatotipes. Physical Culture, Sport and Health of the Nation, 2017; 3(22):587591. (in Ukrainian)

7. Salnykova SV. Physical state improvement of woman aged 30-49 by complex application of aqua-fitness and endogenic hypoxic respiration method. Cand. Diss. Ivano-Frankivsk; 2016. (in Ukrainian)

8. Yoo-Rim Choi, Wan-Suk Choi. Impacts of Korean Somatotype in Energy Consumption and Hormone Changes During Treadmill Gait -Around University Students. The Journal of Korean Society of Physical Therapy. 2011;1:85-92

9. Goran Spori, Daniel Bok, Dinko Vuleta Jr, Dra`en Harasin. Impact of Body Composition on Performance in Fitness Tests among Personnel of the Croatian Navy. Coll. Antropol. 2011;35(2):335-339.

10.Chaouachi M, Chaouachi A, Chamari K, Chtara M, Feki Y, Amri M, Trudeau F. Effects of dominant somatotype on aerobic capacity trainability. Br J Sports Med. 2005;39(12): 954-959. https://doi.org/10.1136/bjsm.2005.019943
11.Brezdeniuk O. Aerobic potentials of 17-21 years old students with different component composition of body mass. Fizichna aktivnist', zdorov'ia i sport, 2014;1:9-18. (in Ukrainian)

12.Sukanta Saha. Somatic and Body Composition Factors Underlying Aerobic Capacity. American Journal of Sports Science 2015; 3(2): 36-40. https://doi.org/10.11648/j.ajss.20150302.12

13. Venkata Ramana, Surya Kumari, Sudhakar Rao, Balakrishna N. Effect of changes in body composition profile on VO2 max and maximal work performance in athletes. Journal of Exercise Physiology Online,_2004;7(1):34-39.

14.Alkandari JR, Barac Nieto M. Somatotype Components, Aerobic Fitness and Grip Strength in Kuwaiti Males and Females. Health, 2016; 8: 1349-1355. https://doi.org/10.4236/health.2016.813135

15.Neha Parve, Madhuri Kulkarni, Hemangini Sarambekar. Study of Static Anthropometric Measurements and Body Somatotypes of Women. International Journal of Scientific and Research Publications, 2015;5(9): 100-115.

16.Kaur G, Singh SP, Singh AP. Age Related Variations in Endomorphic, Mesomorphic and Ectomorphic Components of Somatotype in Urban Women of Punjab. Human Biology Review, 2017;6(1):47-52

17.Lizana PA, González S, Lera L, Leyton B. Association between body composition, somatotype and socioeconomic status in Chilean children and adolescents at different school levels. Journal of Biosocial Science, 2018;50: :53-69. https://doi.org/10.1017/S0021932017000025

18.Karpman VL, Gudkov IL. Indirect definition of the maximum oxygen consumption in athletes of high qualification. Theory and practice of physical culture. 1974; 1:37-41.

19.Carter J, Heath B. Somatotyping - development and applications. Cambridge University Press; 1990.

20.Denisova LV, Hmelnitskaya IV, Harchenko LA. Measurements and methods of mathematical statistics in physical education and sport. Kiev: Olympic literature; 2008. (in Russian) 


\section{Information about the authors:}

Miroshnichenko V.M. (Corresponding author); http://orcid.org/0000-0003-1139-4554; 29miroshnichenko@gmail.com; Department of Physical Education, Faculty of Physical Education, Vinnytsia Mykhailo Kotsiubynskyi State Pedagogical University; OstrozTkoho st., 32, Vinnytsia, 21100, Ukraine.

Salnykova S.V.: http://orcid.org/0000-0003-4675-6105; aqvasveta@ukr.net; Department of Philosophy and Economic, Vinnytsia institute of trade and economics of Kyiv national university of trade and economics; Soborna st., 87, Vinnytsia, 21050, Ukraine.

Brezdeniuk O.Yu.: http://orcid.org/0000-0003- 0844-8777; sandrikk86@gmail.com; Department of Physical Education, Faculty of Physical Education, Vinnytsia Mykhailo Kotsiubynskyi State Pedagogical University; OstrozTkoho st., 32, Vinnytsia, 21100 , Ukraine.

Nesterova S.Yu.: http://orcid.org/0000-0002-9621-0218; svetanest01@gmail.com; Department of Medical and Biological Foundations of Physical Education and Physical Rehabilitation, Faculty of Physical Education, Vinnytsia Mykhailo Kotsiubynskyi State Pedagogical University; OstrozTkoho st., 32, Vinnytsia, 21100, Ukraine.

Sulyma A.S.: http://orcid.org/0000-0003-1858-0085; allasulyma16.83@gmail.com; Department of Medical and Biological Foundations of Physical Education and Physical Rehabilitation, Faculty of Physical Education, Vinnytsia Mykhailo Kotsiubynskyi State Pedagogical University; OstrozTkoho st., 32, Vinnytsia, 21100, Ukraine.

Onyshchuk V.Ye.: http://orcid.org/0000-0002-9615-6653; vitapilgun@yandex.ru; Department of Medical and Biological Foundations of Physical Education and Physical Rehabilitation, Faculty of Physical Education, Vinnytsia Mykhailo Kotsiubynskyi State Pedagogical University; OstrozTkoho st., 32, Vinnytsia, 21100, Ukraine.

Gavrylova N.V.: http://orcid.org/0000-0001-6209-5875; gavrilova.natal83@gmail.com; Department of Medical and Biological Foundations of Physical Education and Physical Rehabilitation, Faculty of Physical Education, Vinnytsia Mykhailo Kotsiubynskyi State Pedagogical University; OstrozTkoho st., 32, Vinnytsia, 21100, Ukraine.

Cite this article as: Miroshnichenko VM, Salnykova SV, Brezdeniuk OY, Nesterova SY, Sulyma AS, Onyshchuk VE, Gavrylova $\mathrm{NV}$. The maximum oxygen consumption and body structure component of women at the first period of mature age with a different somatotypes. Pedagogics, psychology, medical-biological problems of physical training and sports, 2018;22(6):306-312. https:// doi.org/10.15561/18189172.2018.0605

The electronic version of this article is the complete one and can be found online at: http://www.sportpedagogy.org.ua/index.php/PPS/issue/archive

This is an Open Access article distributed under the terms of the Creative Commons Attribution License, which permits unrestricted use, distribution, and reproduction in any medium, provided the original work is properly cited (http://creativecommons.org/licenses/by/4.0/deed.en).

Received: 13.03 .2018

Accepted: 15.04.2018; Published: 22.12.2018 